\title{
Peningkatan Hasil Belajar PPKn Melalui Strategi Pembelajaran Aktif Tipe Giving Question and Getting Answer Pada Peserta Didik Kelas V Sekolah Dasar
}

\author{
Riza Selvinia \\ SD Negeri 04 Serang \\ rizaselvinia10@gmail.com
}

\section{Article History}

received 3/12/2020

\begin{abstract}
The purpose of this research was to improve student learning outcomes in PPKn grade $V$ elementary schools with active learning strategy type Giving Question and Getting Answer (GQGA). The research conducted was a Classroom Action Research (PTK) with three cycles, with each cycle consisting of one meeting. The stages of each cycle are planning, implementing, observing and reflecting. Each meeting is carried out formative test to determine the progress of students. In the first cycle the students who completed after carrying out the formative test were $70 \%$ and a class average 70 . In the second cycle students who completed after carrying out the formative test were $82,5 \%$ dan a class average 77 . In the third cycle students who completed after carrying out formative test were $100 \%$ and a class average 81,75 . These results indicate that active learning strategy type giving question and getting answer (GQGA) can improve student learning outcomes, especially grade V PPKn at SD Negeri 04 Serang academic year 2019/2020.
\end{abstract}

Keywords: learning outcomes, giving question and getting answer, PPKn

\begin{abstract}
Abstrak
Tujuan dari penelitian ini adalah untuk meningkatkan hasil belajar peserta didik pada muatan pelajaran PPKn di sekolah dasar kelas V dengan strategi Pembelajaran aktif tipe Giving Question and Getting Answer. Penelitian yang dilakukan adalah Penelitian Tindakan Kelas (PTK) sebanyak tiga siklus, dengan setiap siklusnya terdiri dari satu pertemuan. Tahapan setiap siklusnya adalah perencanaan, pelaksanaan, observasi dan refleksi. Setiap pertemuan dilakukan tes formatif untuk mengetahui perkembangan peserta didik. Pada siklus I peserta didik yang tuntas setelah melaksanakan tes formatif sebesar $70 \%$ dan nilai rata-rata kelas 70 . Pada siklus II peserta didik yang tuntas sebesar $82,5 \%$ dan nilai rata-rata kelas 77 . Pada siklus III peserta didik yang tuntas sebesar $100 \%$ dan nilai rata-rata kelas 81,75 . Hasil ini menunjukkan bahwa strategi pembelajaran aktif tipe Giving Question and Getting Answer dapat meningkatkan hasil belajar peserta didik khususnya muatan pelajaran PPKn Kelas V SD Negeri 04 Serang Tahun Pelajaran 2019/2020.
\end{abstract}

Kata kunci: hasil belajar, giving question and getting answer, PPKn

Social, Humanities, and Education Studies (SHEs): Conference Series https://jurnal.uns.ac.id/shes 


\section{PENDAHULUAN}

Pendidikan merupakan usaha sadar yang dilakukan oleh manusia untuk mencapai kehidupan yang lebih baik. Dengan adanya pendidikan, manusia dapat mengembangkan potensi yang dimilikinya dan dapat hidup di masyarakat dengan baik. Penyelenggaran pendidikan di negara Indonesia disebut pula dengan pendidikan nasional. Fungsi Pendidikan nasional yaitu mencerdaskan kehidupan bangsa dengan cara membentuk manusia yang cerdas dalam berbagai aspek kehidupan serta mampu menjadi warga negara yang demokratis dan bertanggungjawab. Penyelenggaraan pendidikan nasional harus dapat membentuk manusia-manusia yang cerdas dalam berbagai aspek kehidupan.Pembentukan manusia yang cerdas dalam berbagai aspek, tentu tidaklah mudah. Agar pendidikan nasional berfungsi sebagaimana mestinya, maka diperlukan adanya Standar Nasional Pendidikan untuk menjamin mutu pendidikan nasional. Peraturan Pemerintah Nomor 19 Tahun 2005 tentang Standar Nasional Pendidikan pasal 4 berbunyi "Standar Nasional Pendidikan bertujuan menjamin mutu pendidikan nasional dalam rangka mencerdaskan kehidupan bangsa dan membentuk watak serta peradaban bangsa yang bermartabat."

Standar Nasional Pendidikan merupakan kriteria minimal tentang sistem pendidikan yang bertujuan untuk menjamin mutu pendidikan nasional dalam rangka membentuk manusia yang cerdas dan berkarakter. Terbentuknya manusia yang cerdas dan berkarakter dapat menjunjung martabat bangsa. Adanya Standar Nasional Pendidikan diharapkan dapat mewujudkan pendidikan nasional yang berkualitas baik serta tercapainya tujuan pendidikan nasional. Oleh karena itu, diperlukan upaya penjaminan mutu dalam bidang pendidikan.

Penjaminan mutu dalam bidang pendidikan bukanlah sesuatu yang mudah dilaksanakan. Komponen-komponen pendidikan memberikan pengaruh besar terhadap mutu pendidikan. Komponen-komponen pendidikan yang saling terkait secara terpadu dapat mendorong pencapaian tujuan pendidikan nasional. Salah satu komponen pendidikan yang mempunyai pengaruh besar dalam menentukan mutu pendidikan yaitu tenaga pendidik (guru). Guru merupakan ujung tombak dalam meningkatkan kualitas pendidikan, dimana guru akan melakukan interaksi langsung dengan peserta didik dalam pembelajaran di ruang kelas. Kualitas pendidikan dapat dilihat melalui proses belajar dan mengajar. Artinya, secara keseluruhan kualitas pendidikan berawal dari kualitas pembelajaran yang dilaksanakan oleh guru di ruang kelas. Salah satu indikator kualitas pembelajaran yang baik dapat dilihat dari peningkatan hasil belajar peserta didik.

Dalam melakukan upaya peningkatan hasil belajar peserta didik, guru memegang peranan penting. Guru merupakan praktisi pendidikan yang langsung terlibat dalam proses pembelajaran. Untuk itu, guru perlu memiliki pemahaman yang memadai tentang strategi pembelajaran dan implementasinya di kelas. Strategi pembelajaran adalah salah satu faktor yang mempunyai andil cukup besar dalam pencapaian tujuan pembelajaran. Maka dari itu, dalam menentukan strategi pembelajaran, guru perlu mempertimbangkan beberapa faktor yang berkaitan antara yang satu dengan yang lainnya. Faktor-faktor tersebut antar lain tujuan pembelajaran, karakteristik materi pembelajaran, karakteristik peserta didik, sumber belajar, dan situasi lingkungan sekolah. Penggunaan strategi pembelajaran yang sesuaikan menunjang pencapaian tujuan pembelajaran, sehingga akan mendorong tercapainya tujuan pendidikan yang diharapkan.

Dalam melaksanakan tugasnya sebagai pengajar, guru menyampaikan berbagai mata pelajaran yang termuat dalam kurikulum. Kurikulum pada jenjang pendidikan dasar terdiri dari beberapa kelompok mata pelajaran. Salah satunya yakni kelompok mata pelajaran kewarganegaraan dan kepribadian yang mencakup muatan pelajaran Pendidikan Pancasila dan Kewarganegaraan. Berdasarkan Lampiran Peraturan Menteri Pendidikan Nasional Republik Indonesia Nomor 22 Tahun 2006 tentang Standar Isi 
untuk Satuan Pendidikan Dasar dan Menengah berbunyi: Mata pelajaran Pendidikan Kewarganegaraan merupakan mata pelajaran yang memfokuskan pada pembentukan warga negara yang memahami dan mampu melaksanakan hak-hak dan kewajibannya untuk menjadi warga negara Indonesia yang cerdas, terampil, dan berkarakter yang diamanatkan oleh Pancasila dan Undang-Undang Dasar 1945. Pendidikan Kewarganegaraan juga memiliki peran penting untuk membentuk peserta didik agar menjadi warga negara yang komitmen dan konsisten untuk bisa mempertahankan Negara Kesatuan Republik Indonesia (Madiong, 2018). Hal tersebut berarti bahwa mata pelajaran Pendidikan Kewarganegaraan ini memiliki peran penting yang wajib diberikan kepada para peserta didik sebagai bekal agar dapat hidup bernegara. Oleh karena itu keberhasilannya dalam proses pembelajaran menjadi hal yang sangat penting untuk peserta didik.

Pembelajaran Pendidikan Pancasila dan Kewargenegaraan (PPKn) diharapkan mampu membentuk peserta didik yang ideal memiliki mental yang kuat, sehingga dapat mengatasi permasalahan yang akan dihadapi. Namun selama ini proses pembelajaran mata pelajaran PPKn kebanyakan masih menggunakan paradigma yang lama dimana guru memberikan pengetahuan saja tanpa melibatkan peserta didik dalam kegiatan pembelajaran secara afektif. Guru seringkali mengabaikan proses pembinaan tatanan nilai, sikap, dan tindakan, sehingga mata pelajaran PPKn tidak dianggap sebagai mata pelajaran pembinaan warga negara yang menekankan pada kesadaran akan hak dan kewajiban. Pembelajaran mata pelajaran PPKn cenderung kurang bermakna karena pembelajaran masih berpusat pada guru. Guru mengajar dengan metode konvensional dan mengharapkan peserta didik duduk, diam, dengar, catat dan hafal. Dalam pembelajaran, guru tidak menggunakan media pembelajaran. Hal tersebut mengakibatkan peserta didik tidak aktif bertanya dan menjawab pertanyaan, serta tidak tertarik dengan mata pelajaran PPKn karena membosankan. Akibatnya, aktivitas dan hasil belajar peserta didik rendah.

Penelitian pengaruh strategi pembelajaran aktif tipe Giving Question and Getting Answer terhadap hasil belajar pernah dilakukan oleh Sattya Dewi Larasati,dkk pada tahun 2019. Hasil penelitian menunjukkan bahwa rata-rata $N$-Gain kelas eksperimen sebesar 0.55 dan kelas kontrol sebesar 0.42 . Hasil uji-t menunjukkan bahwa $t_{\text {hitung }}>$ $t_{\text {tabel }}(2.864>2.000)$, Ha dinyatakan diterima. Hal tersebut berarti bahwa terdapat pengaruh yang positif dan signifikan penerapan strategi pembelajaran aktif tipe Giving Question and Getting Answer terhadap hasil belajar peserta didik.

Berdasarkan hasil refleksi pembelajaran PPKn yang dilakukan guru terdapat banyak peserta didik yang mendapat nilai di bawah KKM yaitu 70 . Persentase ketuntasan belajar klasikal pada muatan pelajaran PPKn masih di bawah $75 \%$. Guru belum memanfaatkan media dan strategi pembelajaran secara maksimal. Akibatnya, dalam pembelajaran peserta didik cenderung pasif.

Rumusan masalah pada penelitian ini memfokuskan pada peningkatan hasil belajar PPKn, yaitu Apakah penerapan strategi pembelajaran aktif tipe Giving Question and Getting Answer dapat meningkatkan hasil belajar PPKn pada peserta didik kelas V SD Negeri 04 Serang?. Tujuan dilakukannya penelitian tindakan kelas adalah untuk memberikan solusi pada permasalahan yang muncul dalam pembelajaran di kelas. Tujuan penelitian tindakan kelas yang dilakukan oleh peneliti adalah untuk meningkatkan hasil belajar PPKn pada peserta didik kelas V SD Negeri 04 Serang Kabupaten Pemalang.

\section{METODE}

Pendekatan yang digunakan dalam penelitian ini adalah penelitian kualitatif, yang berawal dari masalah yang ditemukan di lapangan, kemudian direfleksikan dan dianalisis berdasarkan teori yang menunjang kemudian dilakukan tindakan di lapangan. Jenis penelitian ini yaitu penelitian tindakan kelas (action research). Penelitian Tindakan 
kelas memiliki beberapa siklus. Setiap siklus peneliti melakukan empat tindakan yaitu: (1) perencanaan; (2) pelaksanaan, (3) observasi, dan (4) refleksi. Penelitian Tindakan kelas ini dilaksanakan di SD Negeri 04 Serang yang beralamat di Jl. Raya Desa Serang Kecamatan Petarukan Kabupaten Pemalang, Jawa Tengah. Waktu Penelitian dilakukan pada semester 2 tahun ajaran 2019/2020. Subjek penelitian ini adalah peserta didik kelas $\mathrm{V}$ yang berjumlah 40 peserta didik terdiri dari 12 perempuan dan 28 laki-laki. Untuk pengumpulan data diperlukan adanya teknik dan instrumen pengumpulan data. Beberapa instrumen penelitian yang diperlukan dalam penelitian ini diantaranya adalah kisi-kisi soal tes dan pedoman penskoran. Teknik analisis data yang digunakan adalah analisis hasil belajar peserta didik dalam muatan pelajaran PPKn. Data hasil dianalisis dengan presentase sederhana.

\section{HASIL DAN PEMBAHASAN}

Dari hasil penelitian yang telah dilakukan tentang Peningkatan Hasil Belajar PPKn materi kewajiban, tanggung Jawab, dan hak warga masyarakat melalui strategi pembelajaran aktif tipe Giving Question and Getting Answer pada peserta didik Kelas V dapat diuraikan sebagai berikut.

\section{Siklus I}

Pada siklus I membahas materi tentang pengertian kewajiban, tanggung jawab, dan hak warga masyarakat. Pembelajaran dilakukan dengan menerapkan strategi pembelajaran aktif tipe Giving Question and Getting Answer. Pada akhir pembelajaran dilaksanakan tes formatif untuk mengetahui tingkat perkembangan peserta didik selama pembelajaran. Peserta didik mengerjakan tes formatif. Hasil tes formatif peserta didik siklus I dapat dilihat pada tabel 1 berikut.

Tabel 1. Data Hasil Tes Formatif Siklus I

\begin{tabular}{ccc}
\hline Skor $(\mathbf{x})$ & $\mathbf{F}$ & $\mathbf{F x}$ \\
\hline 100 & - & - \\
90 & 2 & 180 \\
80 & 9 & 720 \\
70 & 17 & 1190 \\
60 & 11 & 660 \\
$0-50$ & 1 & 50 \\
Jumlah & 40 & 2800 \\
\hline
\end{tabular}

Tabel 1 menunjukkan bahwa setelah menempuh tahapan rencana dan pelaksanaan tindakan penelitian pada siklus I, terdapat 2 peserta didik yang mendapat nilai 90,9 peserta didik yang mendapat nilai 80,17 peserta didik yang mendapat nilai 70,11 peserta didik yang mendapat nilai 60 , dan 1 peserta didik yang mendapat nilai 50. Adapun KKM muatan pelajaran PPKn adalah 70. Dengan demikian terdapat 28 peserta didik yang telah mencapai KKM dan 12 peserta didik yang belum mencapai KKM. Pada siklus I, ketuntasan belajar peserta didik meningkat menjadi $70 \%$ secara klasikal yang sebelumnya $60 \%$. Nilai tertinggi 90 dan nilai terendah 50 dengan nilai ratarata kelas 70 .

Berdasarkan pelaksanaan kegiatan yang dilaksanakan pada siklus I, menghasilkan perubahan hasil belajar peserta didik namun ketuntasan hasil belajar peserta didik belum mencapai $100 \%$. Hal ini disebabkan beberapa faktor antara lain kekurangan guru dan peserta didik dalam menerapkan strategi pembelajaran dan kekurangan guru dalam mengelola kelas dan mengembangkan media pembelajaran. Oleh karena itu perolehan hasil belajar peserta didik pada siklus I menunjukkan bahwa 
masih ada 12 peserta didik yang mendapatkan nilai di bawah KKM yang ditentukan, yaitu 70, maka tindakan dilanjutkan pada siklus II.

\section{Siklus II}

Pada siklus II membahas materi tentang contoh pelaksanaan kewajiban, tanggung jawab dan hak warga masyarakat. Pembelajaran dilakukan dengan menerapkan strategi pembelajaran aktif tipe Giving Question and Getting Answer. Pada akhir pembelajaran dilaksanakan tes formatif untuk mengetahui tingkat perkembangan peserta didik selama pembelajaran. Peserta didik mengerjakan tes formatif pada akhir pembelajaran. Hasil tes formatif peserta didik siklus II dapat dilihat pada tabel 2 berikut.

Tabel 2. Data Hasil Tes Formatif Siklus II

\begin{tabular}{ccc}
\hline Skor $(\mathbf{x})$ & $\mathbf{F}$ & Fx \\
\hline 100 & 3 & 300 \\
90 & 7 & 630 \\
80 & 12 & 960 \\
70 & 11 & 770 \\
60 & 7 & 420 \\
$0-50$ & - & - \\
Jumlah & 40 & 3080 \\
\hline
\end{tabular}

Tabel 2 menunjukkan terdapat 3 peserta didik yang mendapat nilai 100, 7 peserta didik yang mendapat nilai 90, 12 peserta didik mendapat nilai 80, 11 peserta didik mendapat nilai 70, 7 peserta didik mendapat nilai 60. Adapun KKM muatan pelajaran PPKn adalah 70. Dengan demikian terdapat 33 peserta didik yang telah mencapai KKM dan 7 peserta didik yang belum mencapai KKM. Setelah menempuh beberapa perbaikan dari hasil refleksi siklus I selanjutnya hasil belajar peserta didik pada siklus II meningkat dari $70 \%$ menjadi $82,5 \%$ secara klasikal. Nilai tertinggi 100 dan nilai terendah 60 dengan nilai rata-rata kelas 77 .

Berdasarkan pelaksanaan kegiatan yang dilaksanakan pada siklus II, menghasilkan perubahan hasil belajar peserta didik, namun ketuntasan belajar peserta didik belum mencapai 100\%. Setelah menempuh tahapan refleksi, ditemukan beberapa hal antara lain guru memperbaiki pembelajarannya dengan mendesain strategi pembelajaran aktif tipe Giving Question and Getting Answer agar lebih menarik, misalnya penggunaan media pembelajaran yang bervariasi. Selain itu, guru juga perlu memberikan penguatan atau reward kepada peserta didik yang terlibat aktif dalam proses pembelajaran sehingga dapat memotivasi peserta didik lain untuk turut terlibat aktif dalam proses pembelajaran.

\section{Siklus III}

Pada siklus III membahas materi tentang akibat tidak adanya penerapan tanggung jawab di masyarakat. Pembelajaran dilakukan dengan menerapkan strategi pembelajaran aktif tipe Giving Question and Getting Answer. Pada akhir pembelajaran dilaksanakan tes formatif untuk mengetahui tingkat perkembangan peserta didik selama pembelajaran. Peserta didik mengerjakan tes formatif. Hasil tes formatif peserta didik siklus III dapat dilihat pada tabel 3 berikut.

Tabel 3. Data Hasil Tes Formatif Siklus III

\begin{tabular}{ccc}
\hline Skor $(\mathbf{x})$ & $\mathbf{F}$ & Fx \\
\hline 100 & 5 & 500 \\
90 & 9 & 810 \\
80 & 14 & 1120 \\
70 & 12 & 840 \\
60 & - & - \\
$0-50$ & - & - \\
Jumlah & 40 & 3270 \\
\hline
\end{tabular}


Tabel 3 menunjukkan terdapat 5 peserta didik yang mendapat nilai 100, 9 peserta didik yang mendapat nilai 90,14 peserta didik mendapat nilai 80 dan 12 peserta didik mendapat nilai 70. Adapun KKM muatan pelajaran PPKn adalah 70. Dengan demikian seluruh peserta didik yang telah mencapai KKM. Setelah melakukan sejumlah perbaikan sebagaimana yang ditemukan pada kegiatan refleksi siklus II, ditemukan bahwa ketuntasan hasil belajar pada siklus III meningkat dari $82,5 \%$ menjadi $100 \%$ secara klasikal. Hasil tersebut mengandung arti secara keseluruhan hasil belajar peserta didik dinyatakan tuntas sesuai dengan KKM yakni 70 dengan presentase 100\% yang ditetapkan sekolah. Dengan demikian penelitian tindakan kelas ini dapat diakhiri pada siklus III.

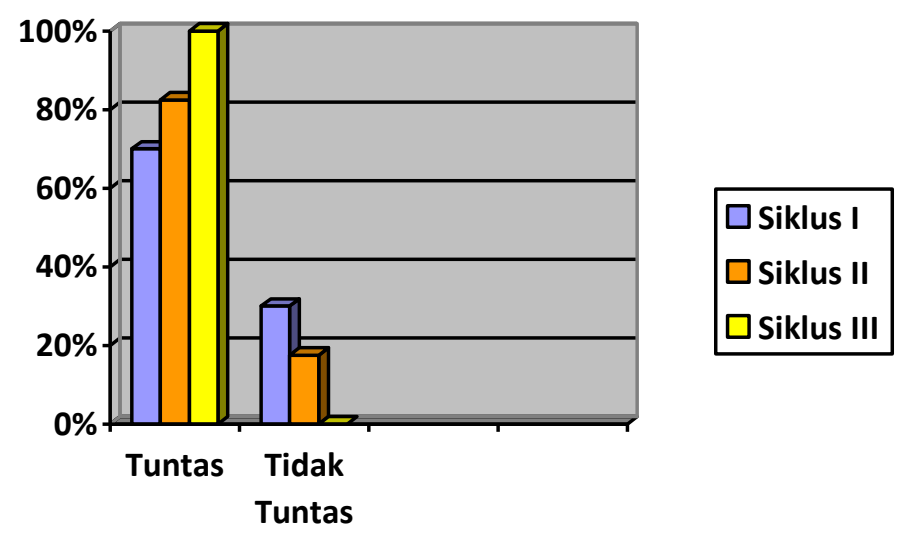

Gambar 1. Perbandingan Hasil Belajar Peserta Didik Siklus I, II dan III

Pada siklus I setelah diadakan tes kemampuan awal dilanjutkan dengan guru dan peserta didik menerapkan strategi pembelajaran aktif tipe Giving Question and Getting Answer. Setelah dilaksanakan siklus I dan dievaluasi dapat dilihat adanya peningkatan hasil belajar yaitu kondisi awal presentase ketuntasan belajar peserta didik sebesar $60 \%$ sedangkan pada siklus I hasil belajar peserta didik mencapai $70 \%$ dengan nilai tertinggi 90 dan nilai terendah 50 dengan nilai rata-rata kelas 70 . Oleh karena masih ditemukan ada 12 peserta didik yang belum tuntas, maka tindakan dilanjutkan dengan siklus II. Pada siklus II, terjadi peningkatan hasil belajar yakni ketuntasan mencapai $82,5 \%$ dengan nilai tertinggi 100 dan nilai terendah 60 serta nilai rata-rata kelas meningkat menjadi 77 . Tindakan dilanjutkan lagi ke siklus III dikarenakan masih ada peserta didik yang belum tuntas atau memenuhi kriteria ketuntuasan minimal (KKM). Pada siklus III, terjadi pula peningkatan hasil belajar karena secara keseluruhan peserta didik dinyatakan telah mencapai KKM 100\% dengan nilai tertinggi 100 dan nilai terendah 70 serta nilai rata-rata kelas 81,75. Penerapan strategi pembelajaran aktif tipe Giving Question and Getting Answer dapat meningkatkan hasil belajar peserta didik. Hasil penelitian ini sesuai dengan penelitian sebelumnya yang dilakukan oleh Sattya Dewi Larasati,dkk (2019) bahwa terdapat pengaruh yang positif dan signifikan penerapan strategi pembelajaran aktif tipe Giving Question and Getting Answer terhadap hasil belajar peserta didik.

\section{SIMPULAN}

Berdasarkan hasil penelitian dan pembahasannya dapat disimpulkan bahwa penerapan strategi pembelajaran aktif tipe Giving Question and Getting Answer dapat meningkatkan hasil belajar peserta didik kelas V SD Negeri 04 Serang pada muatan 
pelajaran PPKn materi kewajiban, tanggung jawab, dan hak warga masyarakat. Peningkatan yang terjadi karena adanya kesan pembelajaran materi yang diajarkan. Peserta didik merasa tertarik dalam pembelajaran sehingga mereka menjadi teringat dengan materi dan dapat membentuk pengetahuannya sendiri. Berdasarkan penelitian yang telah dilaksanakan, strategi pembelajaran aktif tipe Giving Question and Getting Answer merupakan salah satu strategi pembelajaran yang harus dikuasai oleh guru.

\section{DAFTAR PUSTAKA}

Ariyanti, Ida. (2011). Penerapan Strategi Pembelajaran Aktif Tipe Giving Questions and Getting Answer sebagai Upaya Meningkatkan Keaktifan dan Hasil Belajar Biologi Siswa. Skripsi: Universitas Muhammadiyah Surakarta. http://etd.eprints.ums.ac.id/ Hamdani.(2011). Strategi Belajar Mengajar. Bandung: Pustaka Setia.

Madiong, B. (2018). Pendidikan Kewarganegaraan. Makasar: Celebes Media Perkasa. Maharani, T.(2015). Pengaruh Giving Question and Getting Answer Terhadap Hasil Belajar IPA pada Siswa di Sekolah Dasar. Jurnal Untan. Retrived from http://jurnal.untan.ac.id

Kementrian Pendidikan dan Kebudayaan RI.(2006). Lampiran Peraturan Menteri Pendidikan Nasional Republik Indonesia, Nomor 22, Tahun 2006, tentang Standar Isi untuk Satuan Pendidikan Dasar dan Menengah.

Prabawati, I \& Sumantri, M.(2018). Pengaruh Strategi Pembelajaran Giving Question and Getting Answer (GQGA) terhadap Hasil Belajar Matematika. Jurnal Undiksha. Retrieved from http://ejournal.undiksha.ac.id

Republik Indonesia. (2005). Peraturan Pemerintah Nomor 19, Pasal 4, Tahun 2005, tentang Standar Nasional Pendidikan.

Sattya Dewi Larasati,dkk.(2019). Pengaruh Strategi Pembelajaran Aktif Giving Question and Getting Answer terhadap Hasil Belajar. Jurnal Pendidikan Dasar, 1(2). Retrieved from http://jurnal.fkip.unila.ac.id/index.php/pgsd/article/view/18126

Salim, Dkk. (2017), Penelitian Tindakan Kelas, Medan: Perdana Publishing.

Slameto. (2016), Belajar dan Faktor-Faktor yang Mempengaruhinya, Jakarta: PT Rineka Cipta.

Syarif Sumantri, Mohammad. (2016), Strategi Pembelajaran Teori dan Praktik Di Tingkat Pendidikan Dasar, Jakarta: PT Raja Grafindo Persada. 